\title{
Working
}

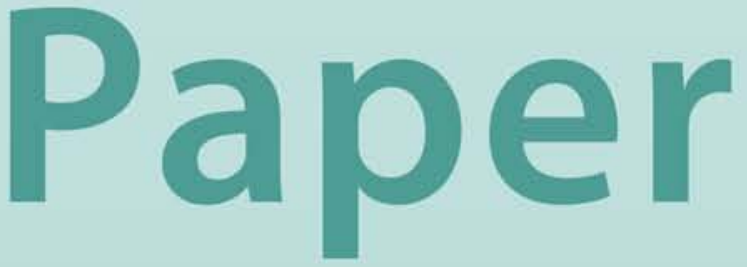


Fat Tails and their (Un)happy Endings:

Correlation Bias and its Implications

for Systemic Risk and Prudential Regulation

Jorge A. Chan-Lau 


\title{
IMF Working Paper
}

\author{
Western Hemisphere
}

\section{Fat-Tails and their (Un)Happy Endings: \\ Correlation Bias and its Implications for Systemic Risk and Prudential Regulation}

\author{
Prepared by Jorge A. Chan-Lau ${ }^{1}$
}

Authorized for distribution by Dora Iakova

April 2011

\begin{abstract}
This Working Paper should not be reported as representing the views of the IMF. The views expressed in this Working Paper are those of the author(s) and do not necessarily represent those of the IMF or IMF policy. Working Papers describe research in progress by the author(s) and are published to elicit comments and to further debate.

The correlation bias refers to the fact that claim subordination in the capital structure of the firm influences claim holders' preferred degree of asset correlation in portfolios held by the firm. Using the copula capital structure model, it is shown that the correlation bias shifts shareholder preferences towards highly correlated assets, making financial institutions more prone to fail and increasing systemic risk given interconnectedness in the financial system. The implications for systemic risk and prudential regulation are assessed under the prism of Basel III, and potential solutions involving changes to the prudential framework and corporate governance are suggested.
\end{abstract}

JEL Classification Numbers: G18, G28, G32, G38

Keywords: Basel III, correlation bias, copula capital structure model, corporate governance, prudential regulation, systemic risk.

Author’s E-Mail Address:jchanlau@imf.org

${ }^{1}$ IMF and The Fletcher School, Tufts University. Stijn Claessens, Dora Iakova, Robert Rennhack and Shahin Shohai offered helpful comments. The views in this paper are solely those of the author, who is responsible for any errors or omissions. Forthcoming in the Journal of Financial Transformation. 
I. Introduction

II. Understanding the Correlation Bias ........................................................................ 4

A. The Basic Contingent Claim Model....................................................................

B. Tail Risk and Correlation ..............................................................................

C. The Copula Capital Structure Model and the Correlation Bias ...............................

III. Correlation Bias, Systemic Risk and Prudential Regulation ........................................... $\underline{9}$

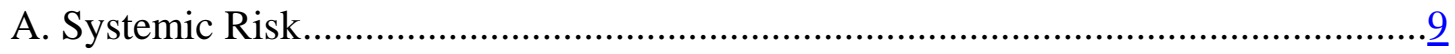

B. Corporate Governance..........................................................................

C. Prudential Regulation ............................................................................

Contingent Capital and Hybrid Securities ...................................................12

Minimum Capital Requirements ........................................................ 12

Systemic Risk Capital Charges ............................................................13

"Skin-in-the-Game” Measures...............................................................14

IV. What may work against Correlation Bias Risk....................................................15

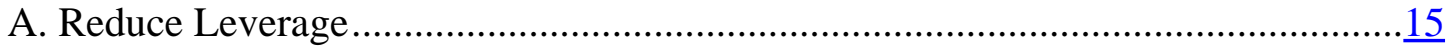

B. Enforce the Volcker Rule and Portfolio Diversification Requirements...................16

C. Force Originators to Hold "Skin, Flesh, and Bones” in Securitized Products .........16

D. Enhance Corporate Control by Debt Holders ...................................................17

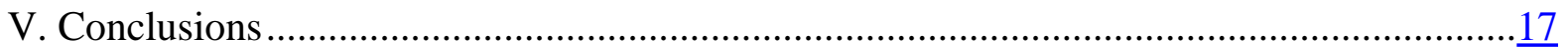

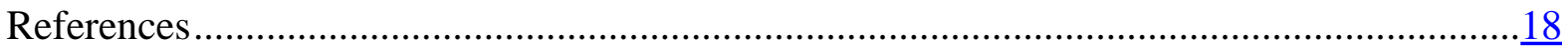

Figures

1. Payoff Schedules of Equity and Debt ........................................................................

2. Profit/Loss of Hypothetical Two-Project Portfolios ............................................................ $\underline{5}$

3. The Analogy Between the Capital Structure of a Tranched Structured Product and the Capital Structure of the Firm ................................................................................... 6

4. Sensitivity of Corporate Claims Value to the Riskiness of a Single Project and to

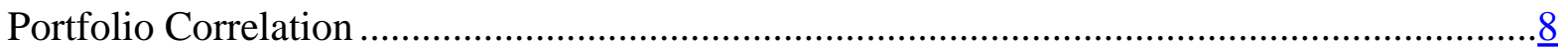

Tables

1. Basel II and Basel III: Capital requirements............................................................13 


\section{INTRODUCTION}

A firm or financial institution that holds a portfolio of diverse projects and/or assets is subject to correlation risk, or the risk arising from the correlation of cash flows accrued to the different projects/assets in the portfolio. Most firms and financial institutions finance their portfolios using a mix of claims, i.e. equity and debt, where each claim is differentiated by its seniority in the capital structure, i.e. equity is subordinated to debt.

The correlation bias is the preference of different claim holders on the firm for different levels of projects/asset correlation in the firm's portfolio. In particular, junior claim holders prefer portfolios where assets are highly correlated while senior claim holders would prefer a more uncorrelated portfolio. Since the control of the firm is usually exercised by managers that tend to act on the behalf of the most junior claim holders, shareholders, the choice of portfolio assets would tend to be biased towards highly correlated assets.

The bias towards highly correlated assets leads to portfolio outcomes characterized by fat tails that increase the likelihood of observing scenarios with extreme upside risk and downside risk. In particular, the lack of diversity in the firm's portfolio increases the likelihood that it may fail since all the assets in the portfolio will be equally affected by a negative shock.

The implications of the correlation bias are not circumscribed to individual institutions though. In a financial system where the correlation bias of junior claim holders is dominant and herd behavior prevalent, it would not be rare to observe "black swan" events often following on the heels of extended periods of tranquility (Taleb, 2009). The stronger the bias of junior claim holders is the more likely is that the financial system will oscillate between extreme periods of tranquility and financial disruption, contributing to increased procyclicality in the event of negative shocks. This is not just a mere theoretical implication: fat tail "tales" and their unhappy endings were dramatically illustrated by the recent global financial crisis originated by subprime problems in the United States.

This paper argues that a copula approach to the capital structure, building on the copula pricing model first developed to analyze structured credit products, provides the right framework for understanding the correlation bias arising from the capital structure of the

firm. Furthermore, the copula capital structure model is a natural generalization of the contingent claim approach to the capital structure of the firm first proposed by Black and Scholes (1973) and Merton (1974). Insights on the correlation bias derived from the copula pricing model are useful to understand how the bias interacts with systemic risk and whether recent financial regulatory reform could address these interactions effectively.

The structure of the remainder of the paper is as follows. Section II establishes in detail the basis for understanding the correlation bias by describing the links between tail risk and asset correlation, and introducing the copula approach to the capital structure. Section III explores how correlation bias influences systemic risk; and assesses whether different regulatory 
proposals and market practices could address the correlation bias effectively. Some potential solutions are suggested in section IV before concluding with section V.

\section{UNDERSTANDING THE CORRELATION BiAS}

\section{A. The Basic Contingent Claim Model}

Black and Scholes (1973) and Merton (1974), by noting that the payoffs to equity and debt were equivalent to options on the asset value of the firm, established the foundations of the contingent claim approach for analyzing the capital structure of the firm. The approach sheds light on the potential conflicts of interest between shareholders and debt holders. Specifically, the payoff of equity, as illustrated in Figure 1, resembles the payoff of a call option where the underlying is the asset value of the firm and the strike price is determined by what is owed to debt holders. Ceteris paribus, shareholders, who hold a long asset volatility position, benefit from projects and/or portfolios that increase the volatility of the firm's asset value, as increased volatility increases the value of the call option. Shareholders, hence, exhibit a high volatility bias while the opposite is true for debt holders.

Figure 1. Payoff Schedules of Equity and Debt

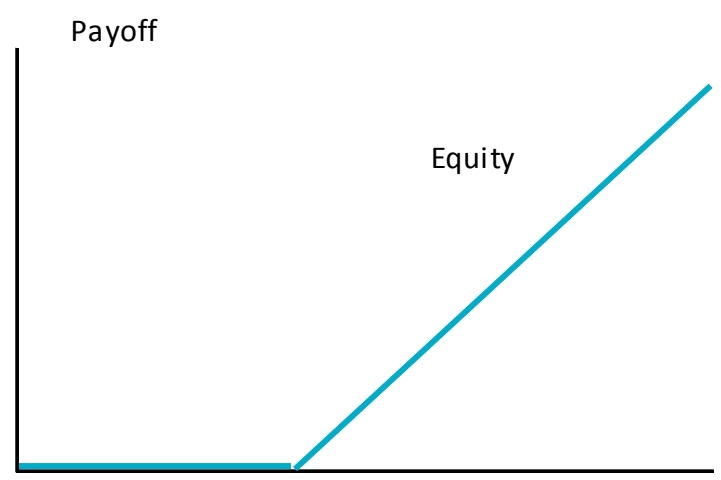

Asset Value of the Firm

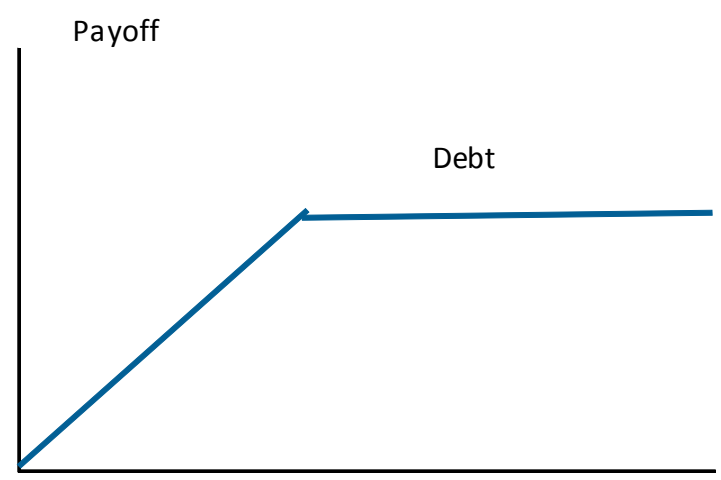

Asset Value of the Firm

While useful for recognizing conflicts of interest between different claim holders, the BlackScholes-Merton capital structure model does not account for the fact that the asset value of the firm is determined by the portfolio of projects and assets held by the firm. The volatility of the profit/loss of the firm, its equity returns, and its asset value are determined not only by the volatility of individual projects but on their mutual dependence (or correlation).

Accounting for the correlation in the firm's project/asset portfolio requires understanding how correlation affects different claims on the firm, which requires setting up an appropriate analytical framework. 


\section{B. Tail Risk and Correlation}

Nevertheless, it can be shown that the basic intuition of the Black-Scholes-Merton capital structure model, that shareholders benefit from increased volatility of the asset value of the firm, extends to the case of a firm undertaking a portfolio of several projects. More importantly, shareholders can increase the volatility of the firm by increasing the correlation among the different projects in the firm's portfolio.

To illustrate this point, assume a firm that can choose between the following two-project portfolios, each one requiring an initial investment of 100 per project. The first portfolio contains projects A and B that are uncorrelated. The probability of success and failure of each project is $1 / 2$. For simplification, it is further assumed a zero rate of return. In case of success, the project returns the original investment of, 100, and in the case of failure, the original investment is lost. The second portfolio contains projects $\mathrm{C}$ and $\mathrm{D}$, with similar characteristics as projects $\mathrm{A}$ and $\mathrm{B}$ in the first portfolio. The only difference is that projects $\mathrm{C}$ and $\mathrm{D}$ are uncorrelated. The three potential profit/loss scenarios are that the project portfolio loses 100 , breaks even at 0 , or gains 100 . Figure 2 shows the probability distribution of each scenario for both portfolios.

Figure 2. Profit/Loss of Hypothetical Two-project Portfolios
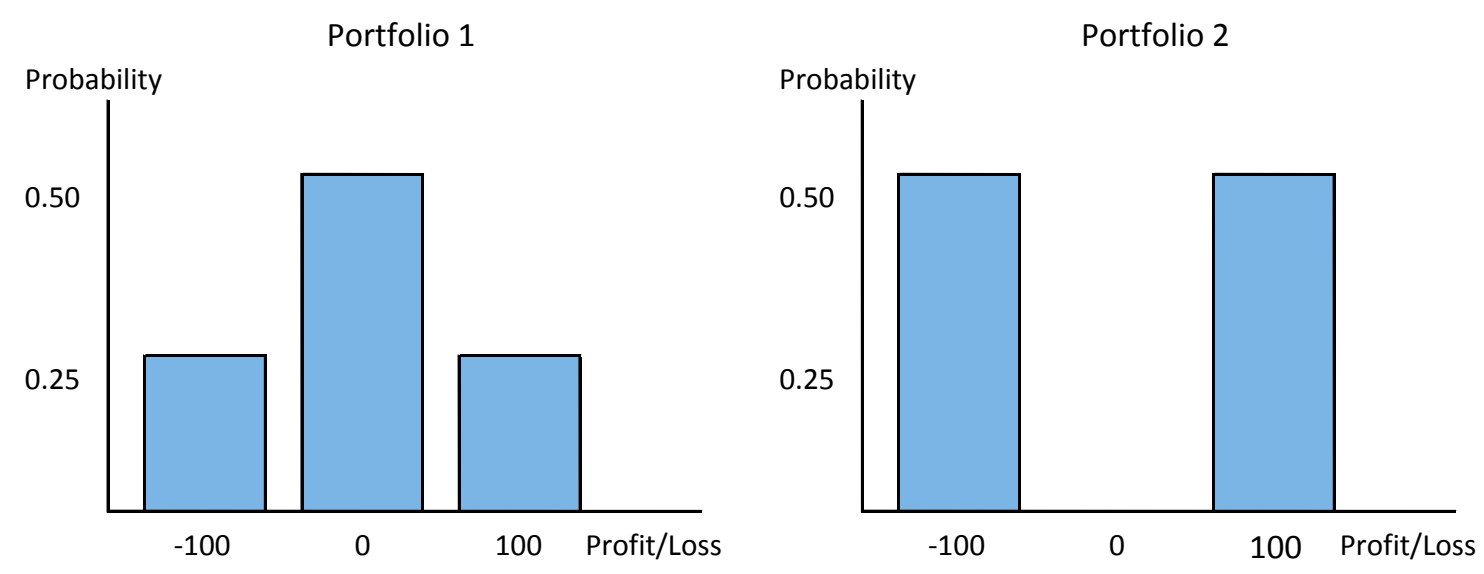

The capital structure financing the portfolio and who controls the firm influence the degree of correlation of the assets in the portfolio. The first and second portfolios both have an expected value of 100 . If the project portfolio is financed only with equity, the shareholders would prefer the first portfolio, as its standard deviation is smaller and the probability of losing money is only 25 percent. Once the project portfolio is financed partly with debt, as the share of debt increases the stronger the incentives for the shareholders to choose the second portfolio, as they would accrue positive returns only in the scenario where both projects are succesful. For instance, for a 50-50 mix of debt and equity, portfolio 1 yields shareholders an expected profit/loss of 25 while portfolio 2 delivers twice that amount, 50 . 
Shareholders, hence, would prefer portfolio 2 even though the odds that the debtholders would suffer a total loss is 50 percent compared to 25 percent in portfolio 1 . In contrast, bondholders would prefer portfolio 1 to portfolio 2 .

\section{The Copula Capital Structure Model and the Correlation Bias}

This section will exploit the analogy between the capital structure of the firm and structured and securitized products to explain how structured credit pricing models can be used as the basis for an analytical and conceptual framework to evaluate issues related to portfolio correlation, systemic risk, and the correlation bias.

To observe this, note that, as in the case of a securitization or structured product, the total asset value of the firm depends on cash flow from their different projects, or in the case of a bank, its bank and trading portfolios. In turn, the value of each corresponding claim depends on its priority over the cash flow, which is determined by the claim relative seniority in the capital structure. Figure 3 shows the analogy between the firm and a structured product. As in the case of structured products, senior debt is protected by the buffer consisting of, in a first instance, equity, and in a second instance, subordinated debt, which are the first, in that order to absorb any loss incurred by the firm or financial institution.

Figure 3. The Analogy Between the Capital Structure of a Tranched Structured Product and the Capital Structure of the Firm
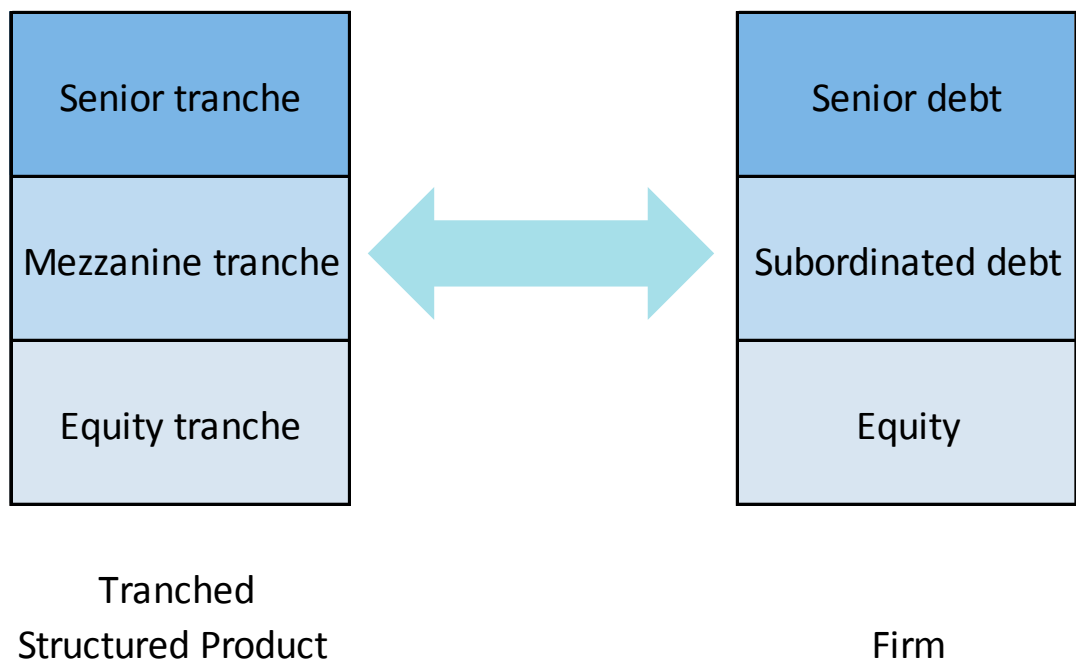

Firm

The observation above suggests that the copula pricing model, as originally proposed by Vacisek (1977) and specialized to the Gaussian copula by $\mathrm{Li}$ (2000), could be the natural framework to analyze conflicts of interest between shareholders and debt holders. The analysis of the capital structure based on the copula pricing model, henceforth, would be referred to as the copula capital structure model. In the copula approach, the value of the projects/assets included in the firm's portfolio is determined by a common factor and a 
project/asset idiosyncratic factor. The correlation of the assets is determined by the correlation of each asset with the common factor. This framework can be easily generated to multifactor copula models. ${ }^{2}$

Furthermore, it can be shown that the copula capital structure model is a natural extension of the contingent claim approach of Black and Scholes (1973) and Merton (1974) since the value of equity is determined by a portfolio of options in several projects, or that each tranche comprises long and short options on the value of the portfolio. ${ }^{3}$ The natural advantage vis-à-vis the contingent claim approach is that the copula approach naturally accommodates several types of claims and the fact that firms hold portfolios comprising multiple projects and assets.

The main insight from the copula approach to the capital structure is that it makes explicit the correlation bias, or differences in claim holders' preferences for the degree of correlation among the different projects/assets held by the firm. The particular instance of the correlation bias that leads to higher idiosyncratic and systemic risk is that associated with the correlation bias of shareholders since they prefer portfolios with highly correlated assets.

Using the copula capital structure model, it is possible to explain how different factors affect the value of the different claims in the capital structure of the firm. One such factor is the riskiness of the individual projects as proxied by their probability of success. An improvement on the odds of success benefits all claims as long as the payoff of a successful project is independent of the riskiness of the project (Figure 4). If the payoff of the project/assets increases with the level of risk, the standard result from the Black-ScholesMerton contingent claim model applies: equity shareholders benefit when the firm undertakes high risk-high return projects. The reason for this result, again, is due to the convexity of the shareholders' payoff which gains the most from upside risks. In contrast, ceteris paribus, an increase in the correlation of the cash flows of the different projects (or assets) and the corresponding increase in the risk correlation of the projects (or assets) benefit shareholders but not senior debt holders.

\footnotetext{
${ }^{2}$ For a concise exposition, see Andersen et al (2003), Gibson (2004), Hull and White (2004), and Chapter 9 in Lando (2004). Coval, Jurek and Stafford (2009) offer an accessible introduction. Rajan, McDermott and Roy (2007) is textbook treatment by market practitioners. The reader should bear in mind, though, that the insights from the copula benchmark model are not restricted to the particular distributional assumptions of the model but extend to other copula models, e.g. Student-t, semi-parametric, and non-parametric copulas.

${ }^{3}$ Rajan , McDermott and Roy (2007).
} 
Figure 4. Sensitivity of Corporate Claims Value to the Riskiness of a Single Project and to Portfolio Correlation
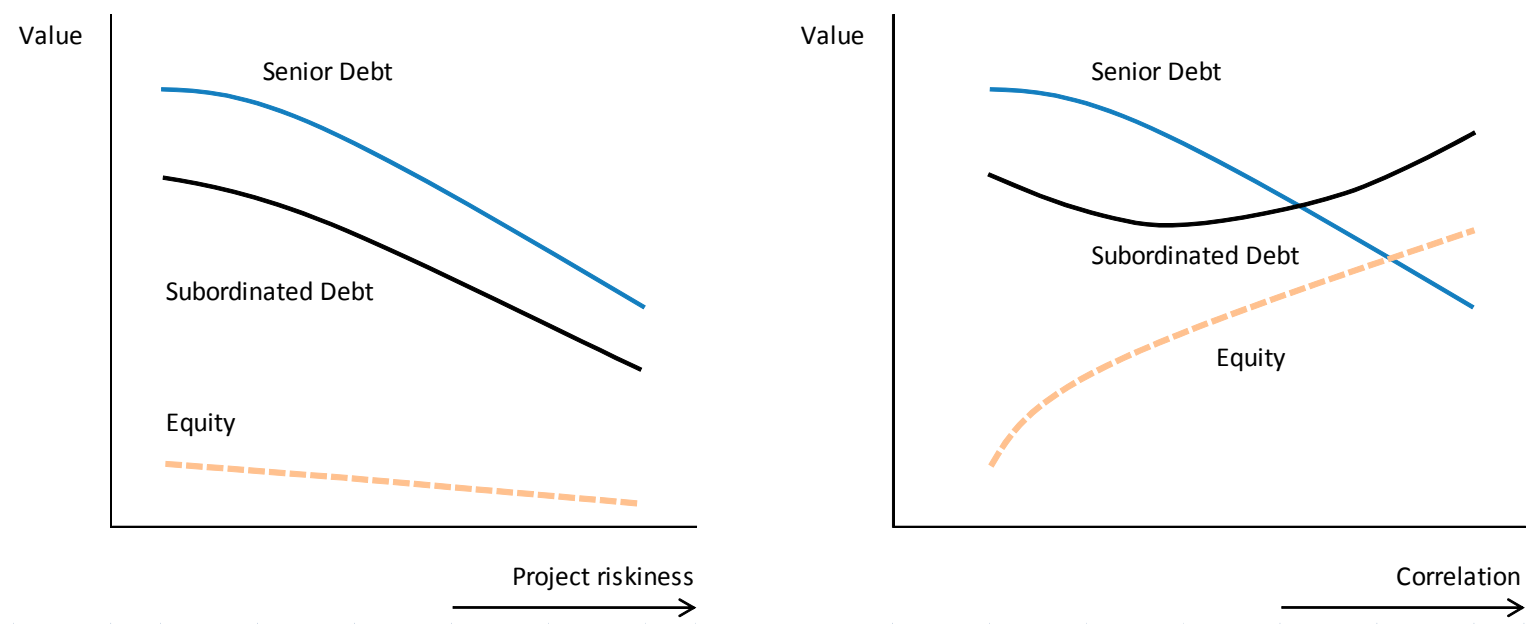

The intuition underlying this result is as follows. Increased risk correlation leads to outcomes where either the majority of projects in the portfolio succeed or fail. In the extreme case of perfectly correlated projects or assets, the outcome is binary, either the portfolio succeeds or the portfolio fails. The downside to shareholders from outcomes close to the binary case is limited to their equity stake in the firm, which only finances part of the total portfolio or assets of the firm. Shareholder, thus, are indifferent to all scenarios where losses exceed the equity of the firm.

The downside scenarios are accompanied by upside scenarios where, due to the high correlation among different projects or assets, the portfolio bears minimal or no losses at all. As in the case of the Black-Scholes-Merton contingent claim model, the upside scenarios benefit shareholders more than debtholders due to the convexity of the payoff structure of the former: they accrue all the gains in excess of what is owed to debtholders. The nature of the payoffs associated to the downside and upside scenarios provides incentives to shareholders to bias the firm's portfolio towards highly correlated projects and/or assets. In contrast, senior debt holders have the opposite bias and would rather prefer that the assets/projects held by the firm exhibit low correlation.

Another important result, which also bears on the design of prudential regulation of financial institutions, relates to how subordinated debt reacts to changes in correlation. The sensitivity of subordinated debt to project/asset correlation is non-monotonic: at low levels of correlation, the value of subordinated debt declines but after a certain threshold is reached, its value starts increasing. Why does subordinated debt exhibit a non-monotonic relationship with correlation?

The answer is as follows: subordinated debt becomes the loss absorbing buffer once the equity buffer is exhausted in case of large portfolio losses. For very low levels of projects/asset correlation, losses are small and are fully absorbed by equity. As correlation 
increases below certain threshold, the losses could potentially exceed the equity buffer forcing partial losses in the value of subordinated debt. Below the threshold, it is in the best interest of subordinated debt holders to keep project/asset correlation as low as possible to maximize the value of their stake in the firm since low correlation minimizes their partial losses. Once the correlation threshold is crossed, however, the loss scenarios would likely imply full losses to subordinated debt holders and would bias their preference towards highly correlated projects/assets since they will maximize the likelihood of a sufficiently low number of failed projects.

The bias of junior claim holders towards highly correlated assets and projects is determined by the relative size of equity and subordinated debt in the capital structure of the firm. ${ }^{4}$ The smaller the size of these subordinated claims (or tranches in structured credit parlance), the stronger the incentive for subordinated claim holders to opt for high correlation on the asset side of the balance sheet. In the case of subordinated debt, the smaller the buffer provided by equity, the lower the threshold correlation would be.

\section{Correlation Bias, Systemic RisK AND PRUdential REgUlation}

The correlation bias, in combination with corporate control, could potentially induce high correlation in the asset and trading portfolios of individual institutions, raising the likelihood of their failure. Since excess portfolio correlation at the individual firm level could translate into systemic risk at the aggregate level it becomes important to assess whether the problems induced by the correlation bias could be addressed through corporate governance and prudential regulation.

\section{A. Systemic Risk}

The design of a prudential regulatory framework should account for the correlation bias exhibited by the different claim holders. On the one hand, if the correlation bias of junior stakeholders dominates the choice of projects and assets included in the firm portfolio, the likelihood that the firm will fail increases. On the other hand, the correlation bias induces both upside and downside fat-tail risk in the portfolio, which could lead to wild swings from periods of tranquility to periods of turmoil. Furthermore, the excess portfolio correlation is compounded by the well documented procyclical behavior of asset correlation which tends to increase during periods of turmoil. ${ }^{5}$

\footnotetext{
${ }^{4}$ For a rigorous but accessible derivation of this and other results in this section, see Gibson (2004) and Coval , Jurek and Stafford (2000).

${ }^{5}$ See, for instance, Hartmann, Straetmans, and de Vries (2004). The increased of asset price correlation during periods of turmoil is prompted by several factors, including liquidity shortages due to fire sales prompted by mark-to-market and risk management practices (Brunnermeier and Pedersen, 2008; Shin, 2008). In general, the
}

(continued...) 
Systemic risk would not be an issue if the failure of a financial institution were an isolated event. The interconnected nature of the financial system, however, raises the risk that an individual failure could have a domino effect on other institutions and prompt serious disruptions across different markets. The interconnectedness nature of the financial system arises from direct linkages between the different market participants, such as the crossinstitutions claims, and from indirect linkages such as exposure to common risk factors and feedback effects increased volatility and declining prices from the use of similar accounting and risk management practices. Furthermore, the failure of one bank could lead to a bank panic and a run on the banking system even in the absence of direct or indirect linkages.

Besides interconnectedness, the impact of the correlation bias on systemic risk can be compounded by herding behavior among financial institutions. Herding behavior, which is rather common in financial markets, increases the chances of facing a too-many-to-fail (TMTF) problem since a single adverse shock could prompt the failure of several institutions holding similar portfolios biased towards highly correlated assets. ${ }^{6}$ Herding behavior could be prompted by several factors, such as reputational issues that cause institutions to mimie each other's investment behavior. ${ }^{7}$ Similarly, the trading strategies of different institutions are likely to converge to specific trades, overcrowding them and raising the possibility of generalized losses in specific sectors of the financial system. The losses incurred by credit correlation traders in 2005 and quantitative alternative asset managers in 2007 are two recent examples of this problem.

The discussion above suggests that reducing systemic risk from correlation bias requires corporate governance structures and regulatory requirements aimed at reducing correlation in the asset portfolio of financial institutions.

\section{B. Corporate Governance}

Correlation bias risk is present when corporate control is exercised by shareholders (or management acting on behalf of shareholders in the absence of informational asymmetries). ${ }^{8}$ In the particular case of banks, the share of equity in the capital structure is relatively small since, in the presence of asymmetric information, high leverage is the market solution to deal with governance problems, as noted by Kashyap, Rajan and Stein (2008). But as noted in

financial system is characterized by procyclicality (Borio, Furfine, and Lowe, 2001), which suggest the need for counter-cyclical regulation (Brunnermeier et al, 2009).

${ }^{6}$ On Too-Many-to-Fail, see Acharya and Yorulmazer (2007).

${ }^{7}$ See Scharfstein and Stein (1990) for an early reference to herding behavior among mutual fund managers; and Bikhchandani and Sharma (2001) for a more recent survey. On herding behavior and fat-tails, see Nirei (2006).

${ }^{8}$ Agency problems between managers and shareholders can be accommodated into the copula approach by noting that managers would be the most junior claimants on the cash flows of the firm's portfolio, and would be even more biased than shareholders towards highly correlated projects and/or assets. 
section II, high leverage would bias the bank even more towards highly correlated assets in its portfolio. ${ }^{9}$

One potential solution for reducing correlation bias risk involves changing the corporate governance of financial institutions to shift some corporate control to claim holders other than shareholders. The simpler way to enable debt holders partial control on the firm would be to require them to hold also some equity on the firm. In the real world it is not uncommon to find that type of structure in bank-based financial systems in Japan and continental Europe, where banks are both lenders to and equity owners in other corporations. ${ }^{10}$ Whether banks' portfolios in these countries are less correlated than in market-based, arms-length financial systems, as those in the United Kingdom and the United States, is an open empirical question.

Absent substantial changes in corporate governance structures and corporate control, the monitoring role of debt holders must be overtaken by prudential regulation. As argued in Dewatripont, Rochet and Tirole (2010), the debt holder base of financial institutions could be too diversified and lack the required expertise to monitor or exercise control efficiently. Moreover, for institutions deemed systemic, there are explicit or implicit guarantees like deposit insurance that work against close monitoring the financial institution. Under such circumstances, prudential regulation needs to fill the monitoring role of debt holders.

\section{Prudential Regulation}

The 2008-9 global financial crisis has prompted a number of reform initiatives to the prudential regulation of banks and financial institutions, including the use of contingent capital, increases in minimum capital requirements, the imposition of systemic risk capital charges and requiring originators of structured and securitized products to have some "skin in the game" to align their incentives with those of investors in securitized notes. The relative merits of these initiatives, from the perspective of the correlation bias, are explored in detail.

\footnotetext{
${ }^{9}$ In emerging market countries, domestic banks are usually controlled by families or financial conglomerate holdings that own a substantial majority of shares. The low leverage of these banks works against correlation bias risk but family or financial conglomerates-controlled firms may raise issues related to the protection of minority shareholders rights.

${ }^{10}$ See Allen and Gale (2000). An added benefit from shared corporate control is that, besides reducing the correlation bias risk, it also helps reducing the agency cost of debt, or underinvestment problem (Chan-Lau, 2001). It should be bear in mind that bank-based financial systems, while effective to reduce correlation bias problems and underinvestment, may generate other problems, such as overinvestment and inefficient liquidation (Allen and Gale, 2000).
} 


\section{Contingent Capital and Hybrid Securities}

Academics, policy makers and market practitioners have argued that the use of contingent capital and/or hybrid securities could help reduce Too-Big-to-Fail (TBTF) risk. ${ }^{11}$ Under this proposal, the capital structure of systemic financial institutions should include two tranches of subordinated claims. The first and most junior tranche would be common equity, and the second most junior tranche would be subordinated debt which will convert to equity once a pre-established, pre-insolvency threshold is crossed, i.e. a decline in the ratio of common equity or regulatory capital to risk-weighted assets ratio.

There are at least two strong arguments for the use of contingent capital. The first argument is that during distress periods, contingent capital facilitates an orderly recapitalization of a bank and/or financial institution especially under circumstances when accessing capital markets and/or obtaining equity capital injections are difficult. The second argument is that the risk of dilution during periods of distress would provide shareholders with incentives to avoid excessive risk taking. At the same time, by removing ambiguity about a potential bailout of subordinated creditors in case of an institution failure, holders of convertible subordinated debt will have strong incentives to price risks correctly. In turn, more reliable prices would have a signalling and disciplinary effect on financial institutions.

While contingent capital could be useful to ensure that banks will be able to comply with minimum regulatory capital requirements under severe circumstances, it cannot address the correlation bias problem successfully. From a functional perspective, contingent capital and hybrid securities can be classified as subordinated debt. Moreover, the convertibility feature forces contingent capital and hybrid securities to resemble equity more closely and induces a stronger bias towards a highy correlated portfolio than in the case of plain subordinated debt. From the perspective of shareholders, the incentives from the equity dilution effect from exercising the convertibility option are offset by the fact that the option increases the subordination of equity in the capital structure. The more subordinated equity is, the stronger the incentives to gamble on increased volatility, including increasing the asset correlation in the banking and trading books.

\section{Minimum Capital Requirements}

In September 2010, the Basel Committee on Banking Supervision (BCBS) announced higher global capital minimum standards for commercial banks following a number of recommendations aimed at revising and strengthening the prudential framework. ${ }^{12}$ The specific recommendations are to enhance the capital quality by imposing a stricter definition

\footnotetext{
${ }^{11}$ See Corrigan (2009), Dudley (2009), Strongin, Hindlian, and Lawson (2009), Tarullo (2009), Tucker (2009), French et al (2010), and BCBS (2010a).

${ }^{12}$ See BCBS (2009, 2010b) and Caruana (2010).
} 
of common equity, i.e. "core capital," and require more capital, by raising the minimum common equity requirements to $4 \frac{1}{2}$ percent of risk-weighted assets (RWA) from 2 percent, and adding a conservation buffer of $2 \frac{1}{2}$ percent on top of it, raising total common equity ratio to 7 percent of RWA. National authorities could also impose a countercylical macroprudential common equity overlay of up to $2 \frac{1}{2} 2$ percent of RWA. Tier- 1 capital requirements are increased to 6 percent, and the minimum total capital requirement remains equal to 8 percent of RWA (Table 1).

Table 1. Basel II and Basel III: Capital Requirements

\begin{tabular}{|c|c|c|c|c|c|c|c|c|}
\hline \multirow{3}{*}{$\begin{array}{l}\text { In percent } \\
\text { of risk- } \\
\text { weighted } \\
\text { assets }\end{array}$} & \multicolumn{7}{|c|}{ Capital Requirements } & \multirow{3}{*}{\begin{tabular}{|c|}
$\begin{array}{c}\text { Additional } \\
\text { Macroprudential } \\
\text { overlay }\end{array}$ \\
$\begin{array}{c}\text { Countercyclical } \\
\text { buffer }\end{array}$ \\
Required \\
\end{tabular}} \\
\hline & \multicolumn{3}{|c|}{ Common Equity } & \multicolumn{2}{|c|}{ Tier 1 capital } & \multicolumn{2}{|c|}{ Total capital } & \\
\hline & Minimum & $\begin{array}{c}\text { Conservation } \\
\text { buffer }\end{array}$ & Required & Minimum & Required & Minimum & Required & \\
\hline Basel II & 2.0 & n.a. & n.a. & 4.0 & n.a. & 8.0 & n.a. & n.a. \\
\hline Basel III & 4.5 & 2.5 & 7.0 & 6.0 & 8.5 & 8.0 & 10.5 & $0-2.5$ \\
\hline
\end{tabular}

Source: Caruana (2010).

In principle, increasing the share of common equity in the capital structure of a bank helps reducing the bias towards highly correlated assets. But the increase in common equity is relative to risk-weighted assets rather than to the total assets of the firm which creates a loophole for banks wishing to exploit the correlation bias. Banks, by concentrating their portfolio on highly correlated low risk-weighted assets could satisfy both the minimum and required capital requirements while reducing common equity and increasing leverage. ${ }^{13}$

The introduction of a non-risk based leverage ratio requiring Tier- 1 assets to no less than 3 percent of non-weighted assets plus off-balance sheet structures could contribute to limit the build up of leverage. Nevertheless, since Tier-1 assets comprise assets other than common equity, the leverage ratio may not be enough to address the correlation bias risk posed by shareholders’ correlation preferences.

\section{Systemic Risk Capital Charges}

Another reform proposal contemplates imposing systemic capital charges, or capital charges, proportional to the contribution to each bank's contribution to systemic risk. ${ }^{14}$ While

\footnotetext{
${ }^{13}$ For a simple account of the problems created by the use of risk-weights, seeTriana (2010), The Economist (2010).

${ }^{14}$ On systemic risk charges, one of the pioneering papers is Acharya (2001). The recent global financial crisis has spurred work in this area, including, among others, Adrian and Brunnermeier (2009), Chan-Lau (2010), Gauthier, Lehar and Sousi (2010), Lester, Pedersen and Philippon (2008), Tarashev, Borio and Tsatsaronis (2009). See also Chapter 13 in Acharya and Richardson (2009), and Brunnermeier et al (2009).
} 
systemic capital charges do not address the correlation bias directly, if the charges reflect how the failure of one bank would spillover to other banks, they could provide incentives for the bank to reduce its default risk, which should be reflected in a relatively diversified banking and trading book.

There are several difficulties, however. One is related to the measurement of how much each bank contributes to systemic risk. The risk measures are based on market measures including but not limited to mark-to-market firm value and profit/loss statements, risk measures based on the prices of equity and bonds or credit default swap spreads, or measures based on a combination of balance sheet data and market prices such as distance-to-default, Moody's KMV expected default frequencies, and Altman Z-scores. ${ }^{15}$ For the systemic risk capital charges to work, the market-based measures need to capture potential spillovers reliably but it is often the case that markets fail to price risk correctly.

Moreover, as described above, the correlation bias of shareholders induces also upside fat-tail risk that could be reflected in long periods of tranquility. If the data available for calculating the systemic risk charge spans such a period, and periods of turmoil have yet to realize, the systemic risk charge could understimate spillover risks. The global nature of systemic financial institutions requires the harmonization of systemic capital charges across different jurisdictions, a feat that could be difficult to accomplish. Finally, the ever evolving nature of investment and trading strategies suggest that the nature of spillovers, and in turn, a bank's contribution to systemic risk is constantly changing therefore banks currently deemed relatively safe from a systemic risk perspective may not be so going forward.

\section{“Skin-in-the-Game” Measures}

The dramatic implosion of the structured credit market in 2008-9, especially for tranched residential mortgage-backed securities, prompted initiatives to require banks originating structured vehicles to have more "skin-in-the-game", or in other words, to hold a relatively risky claim on the vehicles they originate. By forcing banks to have more of their capital at stake when structuring a vehicle, both investors and regulators expect that banks would have incentives to perform due diligence on the collateral assets. In addition, to avoid regulatory arbitrage, the total capital held against all claims or tranches in a securitized product should not be less than the capital that would be held against the collateral assets. ${ }^{16}$

Abstracting from issues related to executive compensation and the short-horizon of managers, the copula capital structure model suggests that more "skin-in-the-game" measures concentrated in junior claims on structured products are bound to fail in offseting

\footnotetext{
${ }^{15}$ See, among others, Adrian and Brunnermeier (2009), Chan-Lau (2009), and Lester, Pedersen and Phillippon (2008),

${ }^{16}$ BCBS (2010).
} 
the correlation bias. ${ }^{17}$ The copula pricing model suggests that a bank holding the most junior, subordinated claim in a structured product has a strong incentive to include as many highly correlated assets as possible, as shown in Figure 4 in section II.

The recent performance of structured vehicles during the 2008-9 crisis suggests that the previous argument rings true. Standard market practice in tranched securitizations and structured products is for the originating bank to retain the equity tranche to assure investors in the more senior tranches that the structured vehicle is safe. Additional safeguards to senior claims include a principal and interest payment waterfall structure which directs first the cash flows from the collateral assets to the payment of principal and interests to senior claims, effectively reducing the maturity of the senior claims (Rajan, McDermott, and Roy, 2009).

None of these safeguards, however, addressed the correlation bias incentives of the originating bank. From the perspective of the copula pricing model framework it is not surprising that, despite these safeguards, the correlation among the collateral assets was way higher than the one used to price and manage the risk of the structured vehicles. While model risk and lack of historical data could also be singled out as responsible for the low correlation estimates used to model the prices of structured vehicles, the recent indictment of an investment bank by the U.S. Securities and Exchange Commission suggests that gaming model parameters such as correlation to benefit a certain group of claim holders is not at all unusual. $^{18}$

\section{What May Work Against Correlation Bias Risk}

The evaluation of the regulatory initiatives, especially Basel III, suggests that they would be rather ineffective for reducing the correlation bias of shareholders in financial institutions. The finding should not be surprising since until now, the correlation bias has not been identified as a potential source of idiosyncratic or systemic risk. The natural question for regulators is what measures could work towards reducing the correlation bias of shareholders.

\section{A. Reduce Leverage}

The simpler solution, probably, is to require financial institutions to hold higher levels of common equity relative to unweighted assets rather than risk-weighted assets. The current Basel III requirements specify a maximum leverage ratio of 33 for Tier- 1 capital, so that the leverage ratio of common equity could exceed that number under certain circumstances. Even if Tier-1 were to comprise only common equity, that recommended leverage ration implies a very thin equity layer supporting the capital structure. Calibrating the maximum

\footnotetext{
${ }^{17}$ On incentives associated with executive compensation see Acharya and Richardson (2009), Part III, and French et al (2010), Chapter 6.

${ }^{18}$ U.S. SEC (2010). The investment bank settled the charge by paying a $\$ 550$ million fine.
} 
common equity leverage ratio would require first setting the acceptable level of risk for a financial institution and evaluate precisely the impact of the correlation bias on the risk of the institution. Alternatively, a rough calibration exercise under simulated conditions could yield rough estimates of common equity leverage ratios deemed safe based on historical experience.

\section{B. Enforce the Volcker Rule and Portfolio Diversification Requirements}

Another solution is to require financial institutions to hold diversified banking and trading portfolios. Since trading portfolios can be relatively complex and the reality of trading implies high frequency changes in the trading portfolios, monitoring the portfolio's degree of asset correlation is extremely difficult, both for supervisory agencies and the institution itself. Probably, the cleanest way to avoid correlation bias risk is to adopt the Volcker rule and ban systemic financial institutions from proprietary trading activities. ${ }^{19}$

In the case of the banking portfolio, existing requirements such as concentration and large position limits work towards increasing portfolio diversification. These requirements, however, are only rough guidelines to ensure portfolio diversification since seemingly unrelated sectors may be actually correlated due to their exposure to common risk factors. One way to ensure diversification would be to establish quantitative limits guided by a risk factor analysis performed by the regulatory agency or by the bank using its own internal models. As indicated before, model risk, and in the case of internal models, incentives to game the system could work against this solution.

\section{Force Originators to Hold “Skin, Flesh, and Bones” in Securitized Products}

The correlation bias shows that investors in structured and securitized products would prefer that the collateral assets exhibit different levels of correlation depending on the subordination of their claims. In particular, senior tranche holders would prefer low correlation while equity holders would prefer high correlation. To align incentives, originators usually hold the equity tranche and waterfall structures that reduce the maturity of senior tranches but these measures cannot address the correlation bias of the equity holders. Rather than holding the riskiest tranche, from a default risk perspective, or "skin-in-the-game”, originators should be required to hold stakes in every single tranche of the structured and securitized product, or in other words they have to put "skin, flesh, and bones" in the game.

\footnotetext{
19 The Volcker rule, initially proposed by former U.S. Federal Reserve Chairman Paul Volcker, was incorporated as section 619 in the Dodd-Frank Act approved by the U.S. Congress on June 27, 2010.
} 


\section{Enhance Corporate Control by Debt Holders}

Moving beyond potential solutions related with the regulatory framework, reducing correlation bias risk may require introducing changes in the corporate governance structure of financial institutions to yield more corporate control to debt holders. The incentives for debt holders to participate actively in the corporate control of a bank are relatively weak.

Banks' debt-like instruments are mainly of a short-term nature, held by a diversified investor base, and in the case of deposits, they are guaranteed by the government. To shift incentives, banks could be required to increase the share of long-term debt in their liabilities, and longterm creditors should be represented in the board of directors. An added benefit of increasing the share of long-term debt is the enhancement of the bank's asset-liability management. Going into this direction would require a careful design of the the balance of power between directors representing shareholders and those representing debt holders. The copula capital structure model could provide guidance towards this end.

\section{Conclusions}

Viewing the firm as a portfolio of projects and assets funded by claims differentiated by their seniority in the capital structure help us to extend the insights of the contingent claim model of the capital structure, based on the Black-Scholes-Merton model, to a copula capital structure model based on the copula structured credit pricing model.

More importantly, by shifting to a portfolio perspective, it becomes straightforward to identify the correlation bias, which influences the preferences of different claim holders for the degree of asset correlation in the firm's portfolios. The junior the claim is the higher the preference for higher asset correlation.

The existence of the correlation bias, combined with the fact that corporate control is exercised by the most junior claimants, suggest that financial institutions including systemic banks may biased their banking and trading portfolios towards highly correlated assets. The portfolio bias could increase the risk that the institution fails, and owing to the high degree of interconnectedness in the financial system, systemic risk would increase since its failure would cause severe market disruptions and raise the likelihood of the subsequent failures.

Because the systemic risk implications of the correlation bias have yet to be recognized explicitly, current prudential regulatory reform initiatives including the use of contingent capital and hybrid securities, systemic risk charges, and market practices like waterfall structures in securitized products cannot reduce correlation bias risk and its impact on systemic risk. Measures that could potentially reduce correlation bias risk include increasing substantially the share of common equity in the capital structure of financial institutions, enforce diversification requirements, ban proprietary trading in systemic institutions, require securitization originators to hold stakes in all tranches of the capital structure of securitized products, and give debt holders some control over the firm. 


\section{REFERENCES}

Acharya, V.V., 2001, “A Theory of Systemic Risk and Design of Prudential Bank Regulation,” working paper (New York: New York University). , and T. Yorulmazer, 2007, “Too Many to Fail - An Analysis of TimeInconsistency in Bank Closure Policies,” Journal of Financial Intermediation, Vol. 16, No. 1, pp. 1-31.

and M. Richardson, editors, 2009, Restoring Financial Stability: How to Repair a Failed System (New York: John Wiley and Sons).

Adrian, T., and M. Brunnermeier, 2009, “CoVaR,” working paper (New York: Federal Reserve Bank of New York).

Allen, F., and D. Gale, 2000, Comparing Financial Systems (Cambridge, MA: MIT Press).

Andersen, L., J. Sidenius, and S. Basu, 2003, “All your Hedges in One Basket,” Risk, pp. 67-72.

Basel Committee on Banking Supervision, 2009, Strengthening the Resilience of the Banking Sector, Consultative Document (Basel: Bank for International Settlements). , 2010a, Proposal to Ensure the Loss Absorbency of Regulatory Capital at the Point of Non-Viability, Consultative Document (Basel: Bank for International Settlements).

, 2010b, “Group of Governors and Heads of Supervision Announces Minimum Global Standards,” press release (September 12).

Bikhchandani, S., and S. Sharma, 2001, "Herd Behavior in Financial Markets,” IMF Staff Papers, Vol. 47, 279-310.

Black, F., and M. Scholes, 1974, “The Pricing of Options and Corporate Liabilities,” Journal of Political Economy, Vol. 81, No.3, pp. 637-54.

Borio, C., C. Furfine, and P. Lowe, 2001, Procyclicality of the Financial system and Financial Stability: Issues and Policy Options, BIS Paper No. 1 (Basle: Bank for International Settlements).

Brunnermeier, K., and L. Pedersen, 2008, “Market Liquidity and Funding Liquidity,” Review of Financial Studies, Vol. 
A. Crockett, C. Goodhart, A.D. Persaud, and H.-S. Shin, 2009, "The Fundamental Principles of Financial Regulation," Geneva reports on the World Economy, Vol. 11 (Geneva: International Center for Monetary and Banking Studies).

Caruana, J., 2010, “Basel III: Towards a Safer Financial System,” speech delivered at the Third Santander International Banking Conference, Madrid (September).

Chan-Lau, J.A., 2001, "The Impact of Corporate Governance Structures on the Agency Cost of Debt,” available at http://ssrn.com/author=96623.

, 2009, "Default Risk Codependence in the Global Financial System: Was the Bear Stearns Bailout Justified?” in G. Gregoriou, editor, The Banking Crisis Handbook (New York: CRC Press).

2010, "Regulatory Capital for Too-Connected-to-Fail Institutions: A Practical Proposal,” forthcoming in Financial Markets, Institutions, and Instruments, Vol. 19, No. 5.

Cont, R., and J.P. Bouchaud, 1998, "Herd Behavior and Aggregation Fluctuations in Financial Markets,” working paper.

Corrigan, G., 2009, “Containing Too Big to Fail,” The Charles F. Dolan Lecture Series at Fairfield University (November).

Coval, J., J.W. Jurek, and E. Stafford, 2009, “The Economics of Structured Finance,” Journal of Economic Perspectives, Vol. 23, No. 1, pp. 3-25.

Dewatripont, M., J.-C. Rochet, and J. Tirole, 2010, Balancing the Banks (Princeton: Princeton University Press).

Dudley, W., 2009, “Some Lessons Learned from the Crisis,” speech delivered at the Institute of International Bankers Membership Luncheon, New York City (October).

The Economist, 2010, “Third Time’s the Charm?” London (September 13).

Forbes, K., and R. Rigobon, 2002, “No Contagion, Only Interdependence: Measuring Stock Market Comovements,” Journal of Finance, Vol. 57, No. 5, pp. 2223-61.

French, K. et al, 2010, The Squam Lake Report: Fixing the Financial System (Princeton: Princeton University Press).

Gauthier, C., A. Lehar, and M. Souissi, 2010, “Macroprudential Regulation and Systemic Capital Requirements,” Working Paper No. 2010-4 (Ottawa: Bank of Canada). 
Gibson, M., 2004, “Understanding the Risk of Synthetic CDOs,” Finance and Economics Discussion Series 2004-36 (Washington, D.C.: Board of Governors of the Federal Reserve).

Hartmann, P., S. Straetmans, and C. de Vries, 2004, “Asset Market Linkages in Crisis Periods,” The Review of Economics and Statistics, Vol. 86, No. 1, pp. 313-326.

Hull, J., and A. White, 2004, "Valuation of a CDO and n-th to Default CDS without Monte Carlo Simulation,” Journal of Derivatives, Vol. 12, No. 2, pp. 8-23 (Winter).

Kashyap, A.K., R.G. Rajan, and J.C. Stein, 2008, “Rethinking Capital Regulation,” Proceedings of the 2008 Jackson Hole Symposium (Kansas City: Federal Reserve Bank of Kansas City).

Lando, D., 2004, Credit Risk Modeling (Princeton: Princeton University Press).

Lester, A., L.H. Pedersen, and T. Philippon, 2008, "Systemic Risk and Macroeconomic Capital,” working paper (New York: New York University).

Li, D.X., 2000, “On Default Correlation: A Copula Function Approach,” Journal of Fixed Income, Vol. 9, No. 4, pp. 43-54.

Merton, R.C., 1974, “On the Pricing of Corporate Debt: the Risk Structure of Interest Rates,” Journal of Finance, Vol. 29, No. 2, pp. 449-70.

Nirei, M., 2006, “Herd Behavior and Fat Tails in Financial Markets,” working paper (Ottawa: Carleton University).

Rajan, A., G. McDermott, and R. Roy, 2007, The Structured Credit Handbook (Wiley).

Shin, H.-S., 2008, Risk and Liquidity, Clarendon Lectures in Finance (Oxford: Oxford University Press).

Scharfstein, David, and Jeremy Stein, 1990, “Herd Behavior and Investment,” American Economic Review, Vol. 80, pp. 465-479.

Strongin, S., A. Hindlian, and S. Lawson, 2009, “Effective Regulation: Part 5 - Ending Too Big to Fail,” Global Markets Institute, Goldman Sachs (December).

Tarashev, N., C. Borio, and C. Tsatsaronis, 2010, “Attributing Systemic Risk to Individual Institutions,” Working Paper No 308.

Tarullo, D., 2009, “Confronting Too Big to Fail,” speech at The Exchequer Club, Washington, DC (October). 
Taleb, N., The Black Swan, Basic Books.

Triana, P., 2010, “Basel III contains seeds of more chaos,” September 19 (London: Financial Times).

Tucker, P., 2009, “The Crisis Management Menu,” speech at the SUERF, CEPS, and Belgian Financial Forum Conference, Crisis Management at the Cross-Roads, Brussels (November).

U.S. Securities and Exchange Commision, 2010, "SEC Charges Goldman Sachs with Fraud in Structuring and Marketing of CDO Tied to Subprimer Mortgages,” press release (April 16).

Vacisek, O., 1977, “Probability of Loss on Loan Portfolio,” Moody’s KMV (San Francisco). 